\title{
X-ray Exposure Reduces the Number of Hippocampal Pyramidal Neurons in Offspring Rats
}

\author{
Fikret Altındağ ${ }^{1^{*}}$, Salih Çibuk ${ }^{2}$ \\ ${ }^{1}$ Department of Histology and Embryology, Faculty of Medicine, Van Yüzüncü Yll University, Van, Turkey \\ ${ }^{2} V$ an Vocational Higher School of Healthcare Studies, Van Yüzüncü Yul University, Van, Turkey
}

\begin{abstract}
$\mathrm{X}$-rays are very important as an imaging tool in the medical diagnosis and treatment of diseases. However, it causes cell damage and death by inducing DNA damage and apoptosis in the hippocampus. The hippocampus is the part of the brain associated with many cognitive functions, especially memory. X-rays cause cell death by stimulating apoptosis in the hippocampus. In the current study, the effects of X-rays on the number of hippocampal pyramidal cells were investigated. A total of 30 rats in three groups were used in the study $(n=10)$. Control group $(C)$; X-ray was not applied. Neonatal group $(\mathrm{N})$; Immediately after birth, newborn rats were exposed to a once-daily non-lethal dose (diagnostic) 8 Gy X-ray for one week. Prenatal+Neonatal group (PN); Pregnant rats were exposed to 8 Gy non-lethal X-rays once daily from the twelfth day of gestation, and newborn rats were exposed to $8 \mathrm{~Gy}$ non-lethal $\mathrm{X}$-rays once daily for one week after birth. Hippocampal pyramidal cell numerical density was calculated by physical dissector counting method. In addition, MDA, SOD and CAT levels were measured in the brain.

Compared with the control group, the numerical density of hippocampal pyramidal cells was significantly decreased in both the $\mathrm{N}$ group and the PN group. While MDA level increased in N and PN groups, CAT level decreased. There was no change in SOD level between groups.

The findings of our study reveal that X-rays reduce the number of pyramidal cells in the hippocampus and therefore may have negative effects on learning and memory.
\end{abstract}

Keywords: Hippocampus, Oxidative stress, Pyramidal cell, Rat, Stereology, X-ray

\section{Introduction}

X-ray imaging, which forms the basis of modern biomedical imaging methods, is the most widely used imaging technique (1). Rapid advances in technology have enabled the active use of imaging for diagnosis and treatment in medicine, and biomedical imaging systems have become an indispensable part of the medical World $(1,2)$. These images systems include X-ray imaging, computed tomography (CT), magnetic resonance imaging (MRI), digital breast tomosynthesis (DBT), nuclear imaging (PET-SPECT), ultrasonography, electrical impedance tomography (EIT), and thermal infrared imaging (IRT) (3).

Ionizing radiation either directly damages the DNA chain or creates oxygen radicals by interacting with molecules in the cell, and these oxygen radicals interact with DNA components, causing breaks in the chain and other types of deterioration (4). Radiation causes random ionization and excitation events in the environment it passes through. Since the cell contains about $70-90 \%$ water, it is likely that the radiation energy will be largely absorbed by the water molecules. The most important mechanisms of action of ionizing radiation (X-rays) are DNA breaks and oxidant damage by increasing the production of free oxygen species (5).

The hippocampus, located in the temporal lobe of the brain, plays a huge role in spatial orientation as well as memory and learning (6). The hippocampus plays a very important role in memory and decides what to keep in memory and what to forget (7). The hippocampus is one of the brain parts most easily affected by radiation (8). The hippocampus is exposed to the harmful effects of ionizing radiation, which is used in the diagnosis of many diseases, especially central nervous system diseases. The severity of cognitive impairment is more pronounced after cranial radiation, especially in children (9). Because neural precursor cells, which are common in the child's brain, are more sensitive to radiation due to their 
proliferative properties (10). Therefore, in our study, we aimed to investigate the effects of Xrays applied to rats during and immediately after pregnancy on the number of hippocampal pyramidal cells using stereological methods

\section{Materials and Methods}

Animals and Experimental Protocol: At the beginning of the study, pregnant rats weighing between 250-300 $\mathrm{g}$ and three pregnant Wistar Albino rats in each group were divided into three groups. After birth, 10 newborn rats obtained from these pregnant rats belonging to the same group were included in the study in three groups. The groups were divided as follows:

Control group (C): Pregnant rats in this group were fed with standard rat chow and water. After birth, ten newborn rats continued to be breastfed for three weeks.

Neonatal group (N): Pregnant rats were not treated until birth, but newborn rats were given a non-lethal dose (diagnostic 8 grays) $\mathrm{X}$-ray once a day for one week.

Prenatal+Neonatal group (PN): Pregnant rats were administered a non-lethal (diagnostic) dose of X-ray once a day from the twelfth day of pregnancy and a non-lethal dose $\mathrm{X}$-ray was administered to newborn rats once a day for one week. After birth, newborn rats continued to be breastfed for three weeks. The rats were housed in cages with constant feed and fresh water in rooms with 12 hours of dark/light applied during the experiment and the temperature set to $22 \pm 2^{\circ} \mathrm{C}$.

At the end of the experiment, the brain tissue of the rats was removed under anesthesia and fixed in formalin. The entire protocol of our study was approved by Van Yüzüncü Yıl University Animal Experiments Local Ethics Committee (Approval number: 2021/08-10).

Stereology: Physical dissector counting method, one of the unbiased stereological methods, which is an unbiased and quantitative method, was used to calculate the hippocampal pyramidal cell numerical density. For stereological evaluation, consecutive sections of $5 \mu \mathrm{m}$ thickness were taken from paraffin-embedded brain tissue with a microtome. The first section was chosen randomly, and the other section was systematically taken every 30 steps. Thus, 10-14 consecutive sections were taken from each tissue block. The first section is called the look-up section and the second section is called the reference section. The consecutive sections taken on the slide were examined under the light microscope after staining with Hematoxylin-Eosin dye. An unbiased counting frame placed on hippocampus sections was used to calculate cells (Figure 1). Hippocampal pyramidal cells observed in the look-up section but not observed in the reference section were counted $(11,12)$. To calculate the numerical density of hippocampal pyramidal cells, the following formula was applied:

$$
\mathrm{N}_{\mathrm{v}}=\frac{\sum \bar{Q}^{-}}{\mathrm{V}_{\text {dis }}}
$$

$\sum \bar{Q}^{-}$: Total number of dissector cells, $\mathrm{V}_{\text {dis: }}$ Total dissector volume

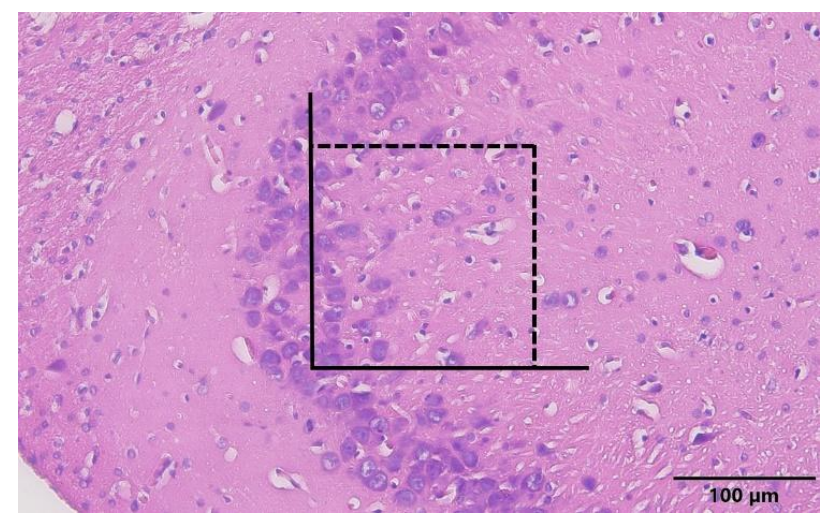

Fig. 1. Placing the unbiased counting frame on the hippocampus. Cells that fall within the counting frame but do not touch the forbidden line (solid line) were counted

Measurement of MDA, SOD and CAT levels In the Brain: MDA, SOD and CAT levels in the brain were measured according to previous reported studies $(13,14,15)$.

Statistical Analysis: The nonparametric KruskalWallis test was used for the analysis of the differences between the groups in the obtained data, and the Mann-Whitney U test was used for the comparison of the paired groups. SPSS 21.0 package program was used for these statistical analyses.

\section{Results}

Stereological Findings: As shown in Figure 2, it was observed that the numerical density of hippocampal pyramidal cells decreased significantly in both the $\mathrm{N}$ group $(\mathrm{p}<0.05)$ and the PN group $(p<0.005)$ when compared with the control group. In addition, when the $\mathrm{N}$ group and PN group were compared, it was observed that the numerical density of hippocampal pyramidal cells in the PN group was significantly lower than in the $\mathrm{N}$ group $(\mathrm{p}<0.05)$. 


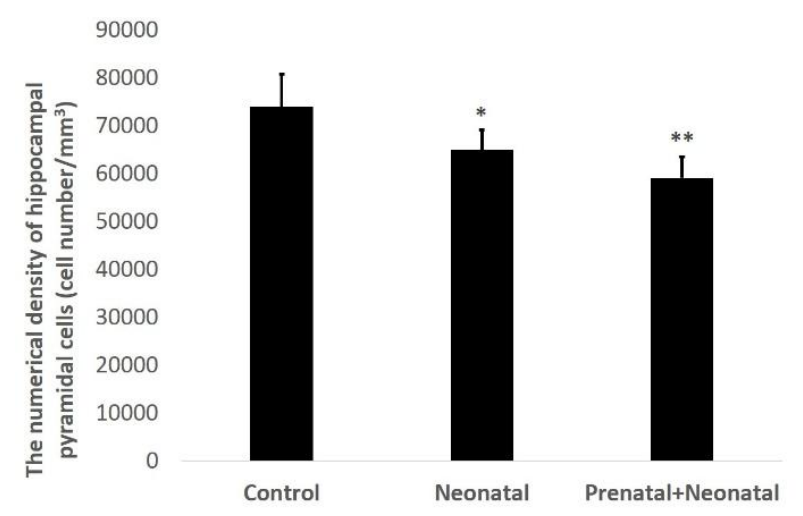

Fig. 2. The effect of X-rays applied to rats in the prenatal and neonatal period on the numerical density of hippocampal pyramidal cells. ${ }^{*}$ denotes a significant decrease compared to the control group $(\mathrm{p}<0.05)$. ${ }^{* *}$ denotes a significant decrease compared to the control group $(\mathrm{p}<0.005)$

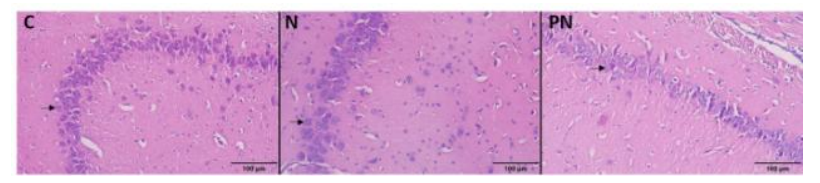

Fig. 3. The effect of $\mathrm{X}$-rays applied to rats in the prenatal and neonatal period on the numerical density of hippocampal pyramidal cells. C: control group, N: Neonatal group, PN: Prenatal+Neonatal group. Arrows indicate hippocampal pyramidal cells. x40. HE.

MDA, SOD and CAT Levels in Rat Brain: Compared to the control group, the MDA level significantly increased in the $\mathrm{N}$ and $\mathrm{PN}$ groups, while the CAT level significantly decreased $(p<0.05)$. However, no significant difference was observed between the groups in SOD level $(\mathrm{p}>0.05)$ (Figure 4)

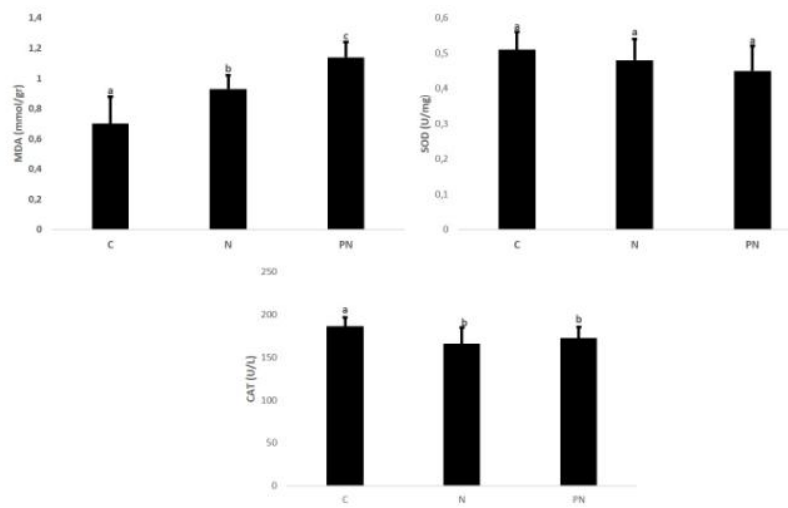

Fig. 4. The effect of X-rays applied to rats in the prenatal and neonatal period on MDA, SOD and CAT levels. Different letters indicate the difference between groups

\section{Discussion}

The effects of radiation on the cell are dosedependent and expressed as Gray (Gy). Gy is defined as the energy trapped in a substance (16). If the pregnant mother is exposed to a dose of $100 \mathrm{mGy}$ before implantation, the dominant effect is the death of the embryo. Harmful effects other than the carcinogenic effect are evident in the organogenesis stage, in the early fetal period, and are less in the second and third trimesters. The risk of developing cancer in childhood increases in fetuses exposed to doses as low as $10 \mathrm{mGy}$. Exposure of the fetus to radiation increases the risk of developing cancer under the age of 15 , and this risk is $6 \%$ for each Gy (17). X-rays have potentially harmful effects on pregnant maternal. However, although rare, pregnant women are necessarily exposed to X-rays for the benefit of the mother or the baby (16).

It has been reported that X-rays cause an increase in lipid peroxidation along with an increase in free radical compounds in neuronal cells (18). Zhang et al. (19) reported that $x$-ray increased MDA level and decreased SOD and CAT levels. Consistent with previous studies, the oxidative stress findings of our study revealed that X-rays increased the level of MDA and decreased the level of CAT in the brain. However, it did not show a significant difference in SOD level. It is thought that the lack of effect of X-rays on SOD level may depend on the applied dose and time $(18,19)$. Since neuron membranes are rich in unsaturated fatty acids in brain tissue, they are affected more quickly by free radicals, and more lipid peroxidation is produced. Thus, the increase in the formation of free radicals has shown that it is important in both the etiology and progression of neurological diseases, affecting both the structure and function of neurons (20). In the treatment of brain tumors or some head and neck tumors, the brain is exposed to ionizing (X-Ray) radiation (21).

The harmful effects of ionizing radiation begin with the formation of free radicals. At this point, the cell's autonomous antioxidant mechanisms come into play and try to inactivate these harmful oxidants in different ways (22). Radiation exposure is closely linked to increased ROS production and persistent oxidative stress in cells $(23,24)$. Mutated DNA is responsible for the harmful effects of radiation on humans (25). Baş et al. (26) reported that there was a significant decrease in the number of pyramidal cells of Cornu Ammonis in the postnatal period as a result of prenatal exposure to electromagnetic field 
radiation, and cell loss with pyknotic cells could be clearly seen. Similarly, Kerimoğlu et al. (27) reported that male rats exposed to a long-term and continuous $900 \mathrm{MHz}$ electromagnetic field during adolescence had a decrease in the number of pyramidal cells in the hippocampus.

It is known that the hippocampus has a low tolerance dose to radiation and plays a very important role in memory events. If tolerance doses are exceeded in head and neck irradiation, very serious memory problems may occur in the patient $(28,29)$. Previous studies have reported that ionizing radiation ( 9 Gry) can cause endoplasmic reticulum stress and cognitive disorders in hippocampal cells (30). Damage to the hippocampus especially causes amnesia and causes people to have various memory problems (31). In addition, neuronal loss in the hippocampus causes hippocampal sclerosis and epilepsy (32).

Previous studies reported that cell proliferation in the hippocampus subgranular zone was significantly reduced on the 120th day after radiotherapy at doses $>5$ Gy (33). In their study, Sun et al (34) reported that X-rays (20Gry) induced apoptosis by increasing the expression of Cdk5 and P25 in the hippocampus and therefore reduced the number of cells in the hippocampus. In parallel, it has been reported that ionizing radiation (10Gry) induces apoptosis in the hippocampus of adult rats by the TUNEL method (35). Similarly, Li et al. (36) reported that 4 Gry ionizing radiation-induced apoptosis by increasing caspase-3 expression in the rat hippocampus. Although the radiotherapy dose used in similar studies in the literature varies between 5 and 20 Gy, 8 Gry doses were used in our study (33). In our study, unlike the literature, the effects of Xrays applied in both prenatal and neonatal periods on hippocampal pyramidal cell numerical density were tried to be obtained by using unbiased stereological methods that allow real or very close to reality findings to be obtained. In our study, it was observed that the number of hippocampal pyramidal cells of rats exposed to radiation (8 Gry) in both prenatal and neonatal periods decreased. In addition, the findings of our study revealed that the $\mathrm{X}$-rays applied in both periods led to more hippocampal neuronal loss compared to the rats in the group administered only in the neonatal period. In parallel with the literature, according to the findings of our study, it is thought that it may be caused by cell death as a result of X-ray-induced apoptosis of the hippocampal neuronal cells $(34,35,36)$.
In conclusion, the findings of our study revealed that exposure to $\mathrm{X}$-rays in the prenatal and neonatal periods may lead to pyramidal cell loss in the hippocampus, which has a very important function in memory and learning events. Therefore, when our findings are evaluated together with the literature, it is thought that Xrays may cause memory and learning loss.

Declaration of Conflicting Interest: The authors declare that there are no conflicts of interest

Acknowledgments: This study was carried out with the resources provided by the Department of Histology and Embryology, Faculty of Medicine.

\section{References}

1. Wolbarst AB, Hendee WR. Evolving and experimental technologies in medical imaging. Radiology 2006; 238: 16-39.

2. Bercovich E, Javitt MC. Medical Imaging: From Roentgen to the Digital Revolution, and Beyond. Rambam Maimonides medical journal 2018; 9:e0034.

3. Kasnak C, Palamutoğlu R. Doğal Antioksidanların Sınıflandırılması ve İnsan Sağlığına Etkileri. Türk Tarım-Gıda Bilim ve Teknoloji Dergisi 2015; 3: 226234.

4. Yaren H, Karayllanoglu T. Radyasyon ve insan sağllğı üzerine etkileri. TSK Koruyucu Hekimlik Bülteni 2005; 4199-208.

5. Venza M, Visalli M, Beninati C, De Gaetano GV, Teti D, Venza I. Cellular Mechanisms of Oxidative Stress and Action in Melanoma. Oxid Med Cell Longev 2015; 481782.

6. Anand KS, Dhikav V. Hippocampus in health and disease: An overview. Ann Indian Acad Neurol 2012; 15:239-246.

7. Armstrong CL, Hunter JV, Ledakis GE, Cohen B, Tallent EM, Goldstein BH, et al. Late cognitive and radiographic changes related to radiotherapy:initial prospective findings. Neurology 2002; 59: 40-48.

8. Greene-Schloesser D, Moore E, Robbins ME. Molecular pathways: Radiation-induced cognitive impairment. Clin Cancer Res 2013; 19: 2294-300.

9. Duffner PK. Risk factors for cognitive decline in children treated for brain tumors. Eur J Paediatr Neurol 2010; 14:106-15.

10. Casciati A, Dobos K, Antonelli F, Benedek A, Kempf SJ, Bellés M, et al. Age-related effects of Xray irradiation on mouse hippocampus. Oncotarget 2016; 7: 28040-28058.

11. Altındağ F, Rağbetli MÇ, Özdek U, Koyun N, Alhalboosi JKI, Elasan S. Combined treatment of sinapic acid and ellagic acid attenuates hyperglycemia in streptozotocin-induced diabetic rats. Food Chem Toxicol 2021; 156: 112443.

12. Mayhew TM, Gundersen HJ. 'If you assume, you can make an ass out of $u$ and me': a decade of the 
disector for stereological counting of particles in 3D space. J Anat 1996; 188: 1-15.

13. Lartillot S, Kedziora P, Athias A. Purification And Characterization Of A New Fungal Catalase. Preparative Biochemistry 1988; 18: 241-246.

14. Sun Y, Oberley LW, Li Y. A simple method for clinical assay of superoxide dismutase. Clinical Chemistry 1988; 34: 4 97-500.

15. Dubovskiy IM, Martemyanov VV, Vorontsova YL, Rantala MJ, Gryzanova EV Glupov, VV. Effect of bacterial infection on antioxidant activity and lipid peroxidation in the midgut of Galleria mellonella L. larvae (Lepidoptera, Pyralidae). Comparative Biochemistry and Physiology Part C: Toxicology \& Pharmacology 2008; 148: 1-5.

16. McCollough CH, Schueler BA, Atwell TD, Braun NN, Regner DM, Brown DL, et al. Radiation Exposure and Pregnancy: When Should We Be Concerned? Radiographics 2007; 27: 909-917.

17. Goldman S, Wagner L. Radiographic ABCs of maternal and fetal survival after trauma: When minutes may count. Radiographics 1998; 19: 13491357.

18. Raber J, Rola R, LeFevour A, Morhardt D, Curley J, Mizumatsu S, et al. Radiation-induced cognitive impairments are associated with changes in indicators of hippocampal neurogenesis. Radiat Res 2004; 162: 39-47.

19. Zhang Y, Cheng Z, Wang C, Ma H, Meng W, Quing Z. Neuroprotective Effects of Kukoamine an against Radiation-induced Rat Brain Injury through Inhibition of Oxidative Stress and Neuronal Apoptosis. Neurochemical Research 2016; 41: 25492558.

20. Pearlstein RD, Higuchi Y, Moldovan M, Johnson K, Fukuda S, Gridley DS, et al. Metalloporphyrin antioxidants ameliorate normal tissue radiation damage in rat brain. Int J Radiat Biol 2010; 86: 145163.

21. Cihan YB, Arsav V, Göcen E. Radyasyonun İndüklediği Beyin Hasarına Karşı Ar1 Sütünün Koruyucu Etkisi. Journal of Neurological Sciences 2011: 29;475-486.

22. Manisalıgil YA, Yurt A. İyonlaştırıcı radyasyonun hücresel ve moleküler düzeydeki etkileri. Düzce Tip Fakültesi Dergisi 2018; 20: 50-53.

23. Hu L, Wang H, Huang L, Zhao Y, Wang J. Crosstalk between autophagy and intracellular radiation response. International journal of oncology 2016; 49:2217-26.

24. Davalli P, Mitic T, Caporali A, Lauriola A, D'Arca D. ROS, Cell Senescence, and Novel Molecular Mechanisms in Aging and Age-Related Diseases. Oxid Med Cell Longev 2016: 3565127.
25. Geleijns J, Broerse JJ, Brugmans MJP. Health effects of radiation exposure in diagnostic radiology. Eur Radiol Syllabus 2004; 14: 19-27.

26. Baş O, Sönmez OF, Aslan A, İkinci A, Hanc1 H, Yildırım M, et al. Pyramidal cell loss in the cornu ammonis of 32-day-old female rats following exposure to a 900 Megahertz electromagnetic field during prenatal days. Neuroquantology 2013; 11: 591-9.

27. Kerimoğlu G, Hancı H, Baş O, Aslan A, Erol HS, Turgut A, et al. Pernicious effects of long-term, continuous $900-\mathrm{MHz}$ electromagnetic field throughout adolescence on hippocampus morphology, biochemistry and pyramidal neuron numbers in 60-day-old Sprague Dawley male rats. J Chem Neuroanat 2016; 77: 169-175.

28. Barani IJ, Benedict SH, Lin PS. Neural stem cells: Implications for the conventional radiotherapy of central nervous system malignancies. Int J Radiat Oncol Biol Phys 2007; 68: 324-333.

29. Gutierrez A, Westerly D, Tome W, Jaradat H, Mackie T, Bentzen SM, et al. Whole brain radiotherapy with hippocampal avoidance and simultaneously integrated brain metastases boost. Int J Radiat Oncol Biol Phys 2007; 69: 589-597.

30. Hinzman CP, Baulch JE, Mehta KY, Gill K, Limoli CL, Cheema AK. Exposure to Ionizing Radiation Causes Endoplasmic Reticulum Stress in the Mouse Hippocampus. Radiat Res 2019; 190:483-493.

31. Spiers HJ, Maguire EA, Burgess N. Hippocampal Amnesia. Neurocase 2001; 7: 357-382.

32. Pitkanen A, Sutula TP. Is epilepsy a progressive disorder? Prospects for new therapeutic approaches in temporal lobe epilepsy. Lancet Neurol 2002; 1: 173-181.

33. Tada E, Parent, JM, Lowenstein DH, Fike JR. Xirradiation causes a prolonged reduction in cell proliferation in the dentate gyrus of adult rats. Neuroscience 2000; 99: 33-41.

34. Sun AM, Li CG, Han YQ, Liu QL, Xia Q, Yuan YW. X-ray irradiation promotes apoptosis of hippocampal neurons through up-regulation of Cdk5 and p25. Cancer Cell International 2013; 13: 1-8.

35. Peißner W, Kocher W, Treuer H, Gillardona F. Ionizing radiation-induced apoptosis of proliferating stem cells in the dentate gyrus of the adult rat hippocampus. Molecular Brain Research 1999; 71: 61-68.

36. Li J, Meng Z, Zhang G, Xing Y, Feng L, Fan S, et al. $\mathrm{N}$-acetylcysteine relieves oxidative stress and protects hippocampus of rat from radiation-induced apoptosis by inhibiting caspase-3. Biomedicine \& Pharmacotherapy 2015; 70: 1-6. 